\title{
$\mathrm{N}_{\mathrm{N}}$ \\ Public Space: The Journal of Law and Social Justice
}

\section{Media Neutrality or Stakeholder Inequality? \\ Why emerging technology requires a rethinking of the stakeholder balance in copyright law}

\section{KG Donovan ${ }^{1}$}

\begin{abstract}
This paper considers a number of emerging technologies and how they challenge the underpinnings of copyright law in Australia. It draws upon the idea that copyright law must 'balance' the rights of stakeholders (creators of works, inventors of technology and users of works) in order to provide the most effective environment for the protection and use of works. This paper further suggests that existing copyright legislation can be divided into provisions that offer rights to creators of works ('front end' provisions), and other provisions that restrict the rights of users and inventors of technology (the 'back end' provisions). It analyses the use of 'media neutral' language in copyright legislation in both the front and back end provisions and argues that the creators of works have far broader rights and protections than those offered in the back end to users and inventors. Further, through an analysis of emerging technologies it is argued that this imbalance offers an environment that restricts the uptake of new technologies and fails to properly foster the protection of the rights of users of these new works and technologies.
\end{abstract}

In no other area of law in Australia is the 'shock of legal uncertainty' more profound than in copyright. ${ }^{2}$ The creation of legislation for copyright is a process of offering rights to the various competing stakeholders involved. This stakeholder balance exists in two distinct but interrelated components of copyright. First, I use the term 'front end' to refer to the provisions of the copyright legislation that offer rights to copyright

1 Student in Bachelor of Laws/Bachelor of Arts in Communications at the University of Technology, Sydney. This paper is based on the author's Honours thesis.

$2 \mathrm{~S}$ Halpern, 'The Art of Compromise and Compromising Art: Copyright, Technology and the Arts' (2003) 50 J CopySoc USA 273 at 280.

Public Space: The Journal of Law and Social Justice (2010) Vol 5, Art 6, pp 1-24. 
holders. Second, I use the term 'back end' to refer to those provisions which limit the rights of copyright holders. Generally, in order to provide sufficient balance between rights holders, rights users and the public there needs to be some sort of balance between this 'front' and 'back' end.

In order to better provide for the emergence of technologies over the past hundred years the legislature has employed various levels of 'media neutral' language in the front and back-end. This has allowed copyright holders to protect their works as new technologies have emerged, and for inventors and the public to have limited rights to use those works. However, since the introduction of the Copyright Act 1968 (Cth) this delicate balance has been altered. Subsequent amendments to the Act have broadened the media neutral language of the front-end provisions whilst neglecting the back-end. The existing legislative framework appears to offer a broad media neutral front-end and a media specific back-end that may not be equipped to deal with emerging technologies.

The Courts have been quite creative in alleviating the imbalance up until now. Already the Courts have found it difficult to construe the back-end of the legislation in such a way as to properly provide for the interests of inventors and the public where these emerging technologies are concerned. ${ }^{3}$ This paper begins with an analysis of media neutrality as it relates to copyright theory and the underlying need to balance the application of media neutrality in copyright. It reviews the balance between the legislative front and back-end over time.

Second, this paper analyses how Courts have construed media neutral language in the legislation and protected existing technologies over the past hundred years in the face of different front-end/back-end balances. This analysis suggests that the Courts have moved from technology-specific construction of legislation in Boosey regarding piano rolls, ${ }^{4}$ to haphazard application of the principle for object code in Computer Edge, ${ }^{5}$ and finally to relatively broad use of the principle for video games as cinematograph films in Sega. ${ }^{6}$ More recent decisions reflect a struggle for the Courts to supplement the imbalance.

Third, this paper reviews the problems that emerging technologies pose to the current copyright legislation. It seeks to identify the various problems generated by new subject matter (the focus being User-Generated Content), new media of fixation (exploring cloud-based streaming), and new means of exploitation (such as antiplagiarism services). These problems can be considered in light of the recent decisions in $\mathrm{iNNe}^{7}$ and IceTV, ${ }^{8}$ highlighting the likely trends in judicial discourse and how this aggravates the potential problems of imbalance.

\footnotetext{
3 See for example Stevens v Kabushiki Kaisha Sony Computer Entertainment (2005) 221 ALR 448 at 491 (Kirby J).

4 Boosey $v$ Whight [1900] 1 Ch 122.

5 Computer Edge Pty Ltd v Apple Computer Inc (1986) 161 CLR 17.

6 Sega Enterprises Ltd v Galaxy Electronics Pty Ltd (1996) 35 IPR 161.

7 Roadshow Films v iiNet (2010) 263 ALR 215.

8 IceTV Pty Ltd v Nine Network Australia (2009) 254 ALR 386.
}

Public Space: The Journal of Law and Social Justice (2010) Vol 5, Art 6, pp 1-24. 


\section{What is media neutral thinking?}

\section{Media Neutrality}

Media neutral interpretation of copyright legislation purports to provide a statute in which little (if any) distinction is made among the technologies by which works may be exploited.' Often called 'technology neutrality' 10 or the 'non-discrimination doctrine' ${ }^{11}$, media neutrality is reading legislative provisions (such as 'author', 'work' and 'writing') in the broadest possible sense, so that copyright does not hold any relevant bias in favour of existing technologies. By not limiting the forms in which copyright subsists the Act promotes the development of new technologies and fosters the creation of works in different forms.

At first glance media neutrality offers rights holders an exclusive right to exploit all future technologies that may in some way contain, embody or provide a distribution platform for their work. And why shouldn't it? If copyright law fails to protect copyright works on future mediums then there is reluctance on rights holders to embrace new technologies. For example, had the term 'sound recordings' not been constructed to include audiotapes in addition to the existing vinyl records then the major music labels may never have adopted the technology. ${ }^{12}$ Media neutrality is thus a method of 'future proofing' the legislation. ${ }^{13}$ But this understanding is limited. It looks at the outcome of media neutrality as proof of its importance - using the doctrine to prove itself. A more sophisticated understanding is garnered from an analysis of the theoretical and historical underpinnings of the doctrine.

\section{Theoretical Underpinnings of Media Neutrality}

Media neutrality is a product of various attempts by lawmakers to achieve content protection in the copyright spectrum and, as such, is rooted deeply in copyright theory. It has not always been a 'user-oriented' doctrine. ${ }^{14}$ There is certainly an attractive quality about a doctrine where copyright is determined by how the end user interacts with content, and that the technology itself is not determinative of what type, or whether at all, copyright exists. Yet as useful as this rationale may be in the contemporary context, it is not descriptive of how copyright developed.

In one sense, the economic philosophy behind copyright is the conviction that the encouragement of individual effort by personal gain is the best way to advance public welfare (being the development of new technologies that better the lives of the

9 Halpern n ,1 295.

10 D Tussey, 'Technology Matters: The Courts, Media Neutrality, and New Technologies' (2005) 12 Journal International Property Law 427, 451.

11 Halpern n 1, 297.

12 Tussey n 9, 433.

13 J Ginsberg, 'Separating Sony sheep from Grokster (and Kazaa) goats: Reckoning future business plans of copyright-dependent technology entrepreneurs' (2008) 19 AIPJ 10, 12.

14 H Tsai, 'Media Neutrality in the Digital Era' (2005) 5 Chi-Kent Journal of Intellectual Property Law 46

Public Space: The Journal of Law and Social Justice (2010) Vol 5, Art 6, pp 1-24. 
general public). ${ }^{15}$ This 'profit motive' ${ }^{16}$ is at the heart of copyright - as the 'right to make copies' usually leads to financial gain. The rationale is that the profit motive maintains the 'engine that ensures the progress of science'. ${ }^{17}$

Once one recognises the existence of a 'right to copy' there very quickly develops a debate about the parameters of that right. What mediums deserve that right? How long does the right last? What exceptions are there? What are the limits? These questions have been (and still are) ${ }^{18}$ quite controversially argued between the three major stakeholders that are affected by the 'right to copy': the inventor of a new technology, the existing rights holder, and the public who access content using new technology. The subsequent balance achieved between these three competing interests is sometimes called the fundamental compromise. ${ }^{19}$ The task for copyright law is to somehow implement this 'fundamental compromise' in a way that maximizes both the public and private good. ${ }^{20}$ Media neutrality is often seen as a tool through which to achieve the stakeholder balance demanded by the fundamental compromise.

Most implementation of media neutrality focuses on the protection of the rights holder by somewhat ignoring the underlying purpose of copyright: to offer a compromise balancing the interests of all stakeholders. This has led to a modern principle with two distinct features. On the one hand media neutral language is used in the rights-giving provisions of legislation and terms are construed broadly so as to protect content on new technologies. On the other, the bargaining power of the inventors of new technologies is limited by focusing on a consultation process that favours the interests of existing rights holders. ${ }^{21}$ It is this flawed use of the principle that has produced our rich, complex and controversial copyright system. ${ }^{22}$ In the digital context, it is particularly important that media neutrality is analysed in the context of the fundamental compromise. ${ }^{23}$ This means that media neutrality somehow needs to operate to balance the rights of all three stakeholders, not merely to favour the existing rights holder. The effect of this balanced application of media neutrality is that rights holders can exploit new technologies through broad 'front-end' provisions, whilst similar 'back-end' provisions allow inventors and the public a right to use content on that technology.

\section{Legislative Developments}

\footnotetext{
15 Halpern n 1, 303.

16 P Goldstein, 'Copyright's Highway: From Gutenberg to the Celestial Jukebox' (2003) 21 (Revised Edition) Stanford University Press

17 Halpern n 1, 301.

18 J Ginsburg, 'How Copyright Got a Bad Name for Itself'. (2002) 26 (1) Columbia Journal of Law and Arts 1, 7.

19 L Lessig, (2004) 'Free Culture: The Nature and Future of Creativity'. The Penguin Press. New York, 92.

20 Halpern n 1, 320.

21 J Litman, (2006) Digital Copyright: Protecting Intellectual Property on the Internet. Amherst, New York. Prometheus Books, 138.

22 Halpern n 1, 303.

23 J Litman, 'Revising Copyright Law for the Information Age' (1996) 75 Orlando Law Review 19, 21.
} 
Although the term 'media neutrality' is recent the problem of media neutrality has long history. As with almost all law at Federation, Australia's copyright legislation mirrored that of the United Kingdom. ${ }^{24}$ The 1842 English legislation ${ }^{25}$ had not been amended to account for leaps in technologies independent of the 'literary work' ${ }^{26}$ Sound recordings were a viable industry with the invention of the phonograph and piano rolls, the cinema was becoming a popular entertainment medium and photography was recognised as a commercial art form.

The first major copyright revision saw the introduction of media specific provisions into both the front and back end - that is, a 'literary work' was limited to literary material in a novelistic sense and did not consider future developments in other mediums. Australia waited until $1912^{27}$ when Britain finally completed a comprehensive revision of copyright ${ }^{28}$ in order to implement effective Australian legislation. The legislation was identical to its English cousin. ${ }^{29}$ Although the new Act purported to 'broaden' copyright in order to protect new types of works, it did so through the use of more media-specific provisions rather than broader definitions of the existing terms. What was deemed to be a 'literary work' continued to be defined narrowly. ${ }^{30}$ Although this allowed the Act to accommodate the specific technologies of the day, it did not allow the Act to offer protection to future works. The legislation was designed so that Parliament would be the recourse for rights holders looking to protect their works on new mediums, rather than leaving it up to the discretion of the courts to narrowly or broadly construe media neutral provisions. The Courts regularly construed terms in the 1912 Act as being limited by dictionary definitions ${ }^{31}$, and despite various amendments rarely ventured beyond these boundaries. ${ }^{32}$

The second major copyright revision during the 1950s and 60s saw the introduction of limited media neutral provisions into both the front and back end of the legislation. The Copyright Act 1968 introduced broader definitions than the law from 1912. The Act clarified cinematograph films ${ }^{33}$, sound recordings ${ }^{34}$ and broadcasts ${ }^{35}$ (the latter was particularly important given the development of cable television as a challenge to conventional terrestrial television ${ }^{36}$ ). It offered a limited media neutral definition of

\footnotetext{
24 Note particularly the Copyright Act 1842 (UK) and the International Copyright Act 1886 (UK)

25 Copyright Act 1842 (UK)

26 P Camina, (2002) Film Copyright in the European Union. Cambridge Press, 65.

27 Copyright Act 1912 (Cth).

28 Copyright Commission (1878) The Royal Commissions and the Report of the Commissioners:

Presented to both Houses of Parliament by Command of Her Majesty (London).

29 Note that the Copyright Act 1911 (UK) formed a sizeable schedule to the 1912 Australian Act.

30 See s 35 (1) of the Copyright Act 1911 (UK).

31 Adelaide City Corporation v Australasian Performing Right Association Ltd [1928] ALR 127 at 131

(Isaacs J).

32 Note that even as late as University of NSW v Moorhouse and Angus \& Robertson Pty Ltd (1975)

133 CLR 1 'authorisation' was construed within the same dictionary-defined limits as Adelaide City

Corp above.

33 Copyright Act 1968 (Cth) s 10.

34 Ibid.

35 Ibid.

36 BD Johnston, 'Rethinking copyrights treatment of new technology: strategic obsolescence as a catalyst for interest group compromise’ (2009) 64 NYU Ann Surv Am L 165, 177.
}

Public Space: The Journal of Law and Social Justice (2010) Vol 5, Art 6, pp 1-24. 
copy so as to protect works in different forms. ${ }^{37}$ It also broadened the scope of 'author' beyond the traditional literary limitations. ${ }^{38}$

Yet for all its apparent scope-broadening provisions the Act did not adopt a broad media neutral doctrine in both the front and back end. Though the term 'media neutrality' would not be identified as a principle until the 1970s, the legislators were aware that the scope of the provisions needed adequate application in order to offer balance between the competing interests. ${ }^{39}$ Realising that they had only limited 'media neutral' scope in the rights-giving provisions of the Act, they understood that there needed to be back-end provisions that balanced this. Thus, they introduced three fair dealing exceptions to copyright use. ${ }^{40}$ In the end the Act wasn't entirely media neutral, but it was balanced between rights-giving and rights-limiting provisions (as both were limited in media-neutral scope).

The third major copyright revision occurred during the 1970s and saw the delicate balance between the front and back end erode. The Government commissioned a Committee led by Franki $\mathrm{J}$ to report on the concerns. ${ }^{41}$ Largely influenced by the United States, ${ }^{42}$ the report delivered by the Franki Committee in 1973 suggested that broad, media neutral front and back end provisions should be introduced. ${ }^{43}$ When the government implemented the recommendations in 1980 there was little left of what the Committee had originally suggested. ${ }^{44}$ What they did introduce were broader notions of 'cinematograph films' and various other works ${ }^{45}$. The final amendment made no revision to the fair dealing provisions to similarly broaden their scope. This saw the front-end grow in media neutral scope.

The fourth significant revision to copyright saw this imbalance continue. In 1984 the legislature was forced to respond to the narrow reading of 'literary work' that had been made by the trial judge in Computer Edge $e^{46}$ (in deciding to exclude computer programs from copyright protection). The amended legislation included computer programs as 'literary works' ${ }^{47}$ and was seen by some as an unnecessary surety - the Federal Court had subsequently overturned the trial decision and read computer programs as literary works. ${ }^{48}$ When the matter reached the High Court two years after

37 Note that in the Copyright Act 1968 (Cth) (as passed) s 10, “copy' ... means any article or thing in which the visual images or sounds comprising the film are embodied"

38 Note that in s 10 and s 35 of the Copyright Act 1968 (Cth) (as passed), s 35 states that "the author of a literary, dramatic, musical or artistic work is the owner of any copyright subsisting in the work"

39 Report to Consider what Alterations are Desirable in the Copyright Law of the Commonwealth (1959) (the 'Spicer Report').

40 Copyright Act 1968 (Cth) ss 40-42.

41 G O'Donnell, (1977) People and authors' rights: The Franki Committee's "compulsory acquisition" copying scheme. Australian Copyright Council, 15.

42 Note particularly the findings of the Register's Report on the General Revision of the U.S. Copyright Law (1961).

43 Copyright Law Committee on Reprographic Reproduction (1976) (the 'Franki Report').

44 Copyright Amendment Act 1980 (Cth).

45 Note for example s 110 of the Act (as passed).

46 Re Apple Computer Inc and Apple Computer Australia Pty Limited v Computer Edge Pty Limited and Michael Suss [1983] FCA 328.

47 Copyright Amendment (Computer Programs) Act 1984 (Cth).

48 Re Apple Computer Inc v Computer Edge Pty Ltd [1984] 53 ALR 225.

Public Space: The Journal of Law and Social Justice (2010) Vol 5, Art 6, pp 1-24. 
the amendments the majority held that the Act prior to Amendment did not protect computer programs in this way. ${ }^{49}$ Shortly after this the Parliament introduced harsher penalties for copyright infringement and strong anti-piracy provisions in $1986 .{ }^{50}$ Thus, the rights-giving provisions (such as what was a literary work and what the penalty was for breaching copyright) was broadened, whilst the rights for users and inventors were tightened.

The fifth major phase for copyright revision came during a string of judicial decisions in the 1990s. In Tape Manufacturers ${ }^{51}$ the High Court recognised the benefits of media neutrality as it had been applied in the United States in Sony ${ }^{52}$ and in the United Kingdom in Amstrad. ${ }^{53}$ The Court in Sega read cinematograph films so as to include video games ${ }^{54}$ and the Court subsequently clarified the scope of computer programs in Data Access. ${ }^{55}$ The legislation itself was amended during this period so as to limit the copyright of journalistic works ${ }^{56}$ as well as to shift the burden of proof to defendants in several types of copyright infringement proceedings. ${ }^{57}$ Thus, the imbalance favouring existing rights holders grew and the back-end was narrowed.

These cases led to the sixth major revision of copyright law. The case law during the 1990s led to the creation of the Copyright Convergence Group and their Discussion Paper, Copyright Reform and the Digital Agenda, which discussed various WIPO Treaty obligations and very broad, media neutral rights. ${ }^{58}$ Their recommendations were introduced with a 2000 Amendment to the Act. ${ }^{59}$ This, and particular amendments generated through the US Free Trade negotiations ${ }^{60}$, sought to allow the Act to 'embrace much of the paraphernalia of modern society' ${ }^{61}$ The definition of 'communicate' was broadened to cover any method by which a work may be distributed (whether invented or yet to be). Thus, the back-end provisions were further narrowed and the rights of copyright holders (such as those involving anticircumvention protection measures, as well as space and time shifting) were extremely limited.

There was potential for a seventh major revision to copyright law in 2005 and it saw the first serious discussion of the back-end provisions. Rather than adopt broad, media neutral back-end provisions suggested by some studies ${ }^{62}$, the 2005 review of fair use

49 Computer Edge Pty Ltd v Apple Computer Inc (1986) 65 ALR 33 at 185 (Gibbs CJ).

50 Copyright Amendment Act 1986 (Cth).

51 Australian Tape Manufacturers Association Ltd v Commonwealth (1993) 176 CLR 480 at 511.

52 Sony Corp of America v Universal City Studios, Inc (1984) 464 US 417.

53 CBS Songs Ltd v Amstrad Consumer Electronics Plc [1988] AC 1013.

54 Galaxy Electronics Pty Ltd v Sega Enterprises Ltd (1997) 145 ALR 21 at 24.

55 Data Access Corporation v Powerflex Services Pty Ltd (1999) 202 CLR 1 at 52.

56 Copyright Amendment Act 1989 (Cth).

57 Copyright Amendment Act 1998 (No 2) (Cth).

58 Copyright Convergence Group. Discussion Paper: Copyright Reform and the Digital Agenda (1997).

59 Copyright Amendment (Digital Agenda) Act 2000 (Cth).

60 US Free Trade Agreement Implementation Act 2005 (Cth).

61 J Litman, (2006) Digital Copyright: Protecting Intellectual Property on the Internet, Amherst, New York, Prometheus Books, 89.

62 See for example Submission to the Attorney-General's Department in Response to the Fair Use and

Public Space: The Journal of Law and Social Justice (2010) Vol 5, Art 6, pp 1-24. 
suggested that specific space and format shifting exceptions be introduced. ${ }^{63}$ It has been argued that these provisions would lack 'broad, forward-looking language' and would merely be 'narrow exceptions carved out of the copyright owners exclusive rights' ${ }^{64}$ Australian Courts have noted this troubling imbalance and have argued that their purpose is to restrict the front-end provisions, rather than broadening the backend. Gibbs CJ in Computer Edge admitted that 'it would be no doubt right to give the Copyright Act a liberal interpretation' however it 'would not be justifiable to depart altogether from its language...in an attempt to protect the products of...technological developments which were not contemplated...when the statute was enacted' ${ }^{65}$ And this ambiguity continues to permeate the Act.

The language used to describe cinematograph films in s 86(c) of the Act anticipates the use of film as the medium to create the content. ${ }^{66}$ It has already been recommended that the true media neutral definition of this type of work should be termed 'audiovisual work'. ${ }^{67}$ The current Act somewhat overcomes this limitation via a broad construction of what it takes to 'communicate [the work] to the public'. ${ }^{68}$ Of course, this is a rather clear example when compared to literary work collections ${ }^{69}$ and television broadcasts ${ }^{70}$. The latter is ironically described in s 87 as including the right to communicate the broadcast 'otherwise than by broadcasting it'. ${ }^{71}$

When one considers that there is an imbalance between broad media neutral front-end provisions and media specific back-end, and that the Courts have recognised this and attempted to artificially construe this balance, the jurisprudence generated from the leading cases is marred by confusion. As recently as Ten Network $v$ Nine the Court unhelpfully concluded that 'a Court is permitted to have regard to the words of the legislature in their legal and historical context, and in appropriate cases, give a meaning that will give effect to any purpose of the legislation that can be deduced from that context'. ${ }^{72}$ The problem with this is that it means that whether copyright protection is afforded to a work is determined subjectively by the Courts rather than objectively by the legislation. Copyright, by its very nature needs to be relatively clear when the work is created and taken to market. Otherwise when a business model is employed and a work exploited a Court has the authority to later find that the work is not entitled to protection.

Welcome to the world of media neutral confusion.

Other Copyright Exceptions Issues Paper 2005 submitted by Apple Computer Inc.

63 Attorney General's Department, Department, Issues Paper: Fair Use and Other Copyright Exceptions: An examination of fair use, fair dealing and other exceptions. (May 2005), 4.

64 Above $\mathrm{n} 35$ at 221.

65 Computer Edge Pty Ltd v Apple Computer Inc (1986) 65 ALR 33 at 42 (Gibbs CJ).

66 See Copyright Act 1968 (Cth) s 10 for the definition of 'cinematograph film'.

67 The notion of the 'audiovisual work' was also considered by the High Court in Network Ten Pty Ltd

$v$ TCN Channel Nine Pty Ltd (2004) 205 ALR 1.

68 Copyright Act 1968 (Cth) s 10.

69 See s 44 of the 1968 Act.

70 See s 87 of the 1968 Act.

71 Copyright Act 1968 (Cth) s 87 (c).

72 Network Ten Pty Ltd v TCN Channel Nine Pty Ltd (2004) 205 ALR 1 at 4, describing the finding in Newcastle City Council v GIO General Ltd (1997) 191 CLR 85 (emphasis added). 


\section{How have the courts dealt with past technologies?}

It's (somewhat) simple to outline the legislative developments and squeeze the developments into the theory suggested by this paper: that media neutral language is not, but should be, used in both the front and back end of the legislation. The more difficult task is to figure out whether the Courts have found this to be much of a problem at all - and if they have - whether the Courts are already equipped to deal with the problems of the imbalance.

Commentators have continually reiterated that 'copyright was technology's child from the start $^{73}$ and that as such it should not be seen to exert control over technological development. Rather, it should be informed by technological development. Below we look at the advent of film as it challenged theatre owners and the accommodation of video games as cinematograph films in Sega. We can also appreciate how the early copyright legislation struggled to grapple with the advent of piano rolls and player pianos in White-Smith and in Boosey. Further, we look into the struggle to accommodate computer programs as literary works in Computer Edge.

\section{Video Games as Films}

When film first became popular in the early twentieth century the copyright system was far from capable of accommodating the new subject matter. In Germany the early thinking was that (because of the use of complicated film projection equipment) film should be protected as a 'mechanical work' in much the same way that patents currently protect mechanical design. ${ }^{74}$ In the United States the Courts determined that because films operated with reels of 24 frames per second, each frame was copyright protected as a photograph under the 1909 Act. ${ }^{75}$ Most films of this era ran for forty minutes or less so as far as copyright was concerned a film consisted of at least 58,000 individual photographs. Congress was forced to amend the Act to include films in 1912. ${ }^{76}$ Britain (and hence Australia) created the specific provision for protection of 'dramatic works'. ${ }^{77}$

The interest is not so much in the specific category through which film was adopted (as an 'audiovisual work' in the US ${ }^{78}$ or as a 'dramatic work' in Britain and Australia) but the way in which the legislation was structured in order to balance the interests of stakeholders at this fork in the road. Due to the brevity of the American rights-giving provision Congress chose not to limit the fair use doctrine enunciated in Folsom $v$ Marsh.$^{79}$ In the US this resulted in a broad statutory front-end (rights giving provision covering all 'audiovisual works') balanced by a broad common law back-end (fair use doctrine). This balance allowed subsequent developments - television, Betamax, VHS

\footnotetext{
73 P Goldstein, 'Copyrights highway: From Gutenberg to the Celestial Jukebox' (2003) 21 (Revised Edition) Stanford University Press, 34.

74 P Camina, (2002) Film copyright in the European Union. Cambridge Press, 77.

75 Copyright Act 1909 (US).

76 Copyright Amendment Act 1912 (US).

77 Copyright Act 1911 (UK), Copyright Act 1912 (Cth).

78 Copyright Act 1909 (US).

79 Folsom v Marsh 9 F Cas 342, 347 (1841) (Justice Joseph Story).
}

Public Space: The Journal of Law and Social Justice (2010) Vol 5, Art 6, pp 1-24. 
and DVD - to be easily subsumed into copyright law with little, if any, need for statutory amendment. In Britain and Australia (along with Canada, Singapore, New Zealand and South Africa) the media specific rights-giving provision providing protection for 'dramatic works' was offset by limits to that right (such as $\mathrm{s}^{4} \mathrm{~A}^{80}$ ). Again, this allowed (though in a much more narrow scope) the accommodation of new technologies and new concerns affecting the balance between stakeholders.

When videogames arrived on the market this fragile balance had shifted. The US had very broad legislative front and back-end as of $1976 .{ }^{81}$ Australia had many more media specific rights-giving provisions and the introduction of specific fair dealing exceptions as of $1968 .{ }^{82}$ Most of the former Commonwealth countries adopted similar provisions between 1956 and 1988.

The question of how effective this balance worked was put to the test in Galaxy Electronics $v$ Sega Enterprises in $1997 .{ }^{83}$ The question was whether videogames came within the ambit of copyright protection outlined in s 10 and s 24 covering 'cinematograph films ${ }^{\text {, } 4}$. The only way for the Court to read videogames in such a way was to adopt a media neutral approach to the definition of film. Justice Wilcox held (Lockhart $\mathrm{J}$ agreeing ${ }^{85}$ ) that 'it would be wrong to interpret narrowly the definition of "cinematograph film" 86 and that the Act was "intended to cover new technologies' ${ }^{87}$ Key to his media neutral analysis was the finding that the emphasis should be 'on the end product...rather than the means adopted to create those pictures' ${ }^{88}$ However, Wilcox $\mathrm{J}$ qualified this reading by finding that 'the definition will apply to any particular new technology only if that technology satisfies the words of the definition, liberally read' ${ }^{89}$ The Court recognised that the trial judge, Burchett $\mathrm{J}$, was correct in finding that 'the legislative history shows Parliament intended to take a broad view in relation to copyright in a film and not to tie the copyright to any particular technology'. ${ }^{90}$

The Court came to such a balanced conclusion by refusing to look at the specific computational method of producing images or how the user interacted with the content, instead Wilcox $\mathbf{J}$ offered a novel solution that if one looked to the potential pirate one would see that 'the copier could place a video camera in front of the game screen and video the images that appeared during the course of a game [and that] the resultant video film would comprise only that game; it would reflect the player input

80 Copyright Act $1911 \mathrm{~s} 41 \mathrm{~A}$ - outlining that one cannot make a threat as the copyright owner without cause.

81 Copyright Act 1976 (US).

82 Copyright Act 1968 (Cth) ss 40-41, s 41A (the satire and parody provision) was added later.

83 (1997) 145 ALR 21.

84 Note that in the Copyright Act 1968 (Cth) s 10 defines the parameters of the cinematograph film and s 24 concerns 'sounds and visual images embodied in an article or thing'.

85 Galaxy Electronics Pty Ltd v Sega Enterprises Ltd (1997) 145 ALR 21 at 22.

86 Ibid 22 (Wilcox J).

87 Ibid 24 (Wilcox J).

88 Ibid.

89 Ibid 31 (Wilcox J).

90 Sega Enterprises Ltd v Galaxy Electronics Pty Ltd (1996) 35 IPR 161 at 165 (Burchett J)

Public Space: The Journal of Law and Social Justice (2010) Vol 5, Art 6, pp 1-24. 
of that particular game'.91

However, by the time the Court came to decide Australian Video Retailers the Court was reluctant to broaden the scope of the definition of 'computer programs' where DVDs were concerned. ${ }^{92}$ This is most likely because the Digital Agenda Amendment significantly shifted the balance between stakeholders in the copyright spectrum. If we turn to the current legislative scope outlined above we can see that this balance has shifted significantly from what it was when video games were comfortably accommodated within the scope of the film provision (1997).

\section{Piano Rolls}

An Australian Court has never directly considered piano rolls or player pianos. Our remoteness, limited technology (until relatively recently), shipping delays and our observance of English common law has resulted in no Australian Court ever needing to rule on the potential copyright infringement of piano rolls. However, Australian Courts in their exploration of computer programs and films have heavily drawn upon the developments of the English and American Courts and their respective discussions of piano rolls. The complexity of the cases, the issues they consider, and their continued relevance to Australian Courts is why it is essential to consider the cases which dealt with player pianos, despite them being non-Australian cases.

The issue first came to a head in the English case of Boosey and reared its head again in the American case of White-Smith. The late 19th century saw the first challenge to copyright with the advent of player pianos and piano rolls. Up until then, in order to hear a musical piece, one needed to attend a live performance or purchase sheet music and play the piece on a piano. Piano rolls were developed in order to allow pianos to play automatically, reading rolls of paper with notches indicating various piano notes. The developers of the technology and subsequent business markets that sold piano rolls paid no royalty to the original composers of the music. ${ }^{93}$

In 1899 the English Courts were asked in Boosey $v$ Whight whether this constituted infringement. ${ }^{94}$ The question was then posed to the American Courts in 1908 in the case of White-Smith Music Publishing v Apollo. ${ }^{95}$ Neither in the US nor Britain was the Court willing to extend the rights of the copyright owner to cover the use of the piano roll. The Courts read the definition of what constituted a 'copy' under the respective Copyright Acts as being incapable of including technologies beyond the scope of the original work. ${ }^{96}$ Thus, even though the melody played by the piano roll was identical to that which was transcribed by composers in their sheet music, the definition of copy was media specific and could not accommodate new technologies. Prima facie, the legislation (being medium specific) favoured the interests of the

91 Galaxy Electronics Pty Ltd $v$ Sega Enterprises Ltd (1997) 145 ALR 21 at 30 (Wilcox J).

92 Australian Video Retailers Assoc'n v Warner Home Video Pty Ltd (2001) 114 FCR 324 at 326.

93 Boosey v Whight [1900] 1 Ch 122.

94 Ibid.

95 White-Smith Music Publishing Co v Apollo Co 209 US 1 (1908).

96 D Tussey, 'Technology Matters: The Courts, Media Neutrality, and New Technologies' (2005) 12 Journal of Intellectual Property Law 427, 438.

Public Space: The Journal of Law and Social Justice (2010) Vol 5, Art 6, pp 1-24. 
inventors of new technologies. The emerging piano roll industry argued that 'the only rights afforded to the copyright owner [were] those set out in the statute' ${ }^{97}$ The Court in both jurisdictions agreed. This was a concern raised by counsel in Sega and Wilcox J acknowledged that everything begins with the rights afforded by the statute. ${ }^{98}$

Intense lobbying of Congress in the United States and Parliament in Britain led to the 1909 and 1911 Copyright Acts respectively. These new Acts marked an interesting innovation, providing copyright owners with 'the exclusive right to produce any mechanical device capable of recreating the sounds of the musical composition'. ${ }^{99}$ Post-amendment the legislation appeared to favour the interests of existing copyright holders. However, the legislation in both jurisdictions recognised that if they were going to put in place a scheme for the protection of existing content on the new technologies then there needed to be sufficient back-end to offer public uses and exploitation rights for inventors. 'Compulsory licences' were adopted (including in Australia) to offer a reprieve for these other stakeholders. ${ }^{100}$ These licences were media specific.

Thus, what resulted were media specific front-end provisions capable of protecting content on some new technologies, but back-end compulsory licences which were similarly designed with media specific focus so as to provide sufficient balance for the other stakeholders. It may not have been perfect, but it worked.

\section{Computer programs}

It is often frustrating for those writing in the field of Australian copyright discourse to offer an Australian-specific analysis of contemporary issues. ${ }^{101}$ Often many of the interesting issues that confront copyright - VHS recording of programs, ${ }^{102}$ transfer of music from CD to a hard disk ${ }^{103}$ - are engaged in the United States Courts long before Australia has the opportunity to discuss the issues. This often leads to Australian lawmakers changing legislation to reflect changes in the United States before Australian Courts have ever engaged the issue. ${ }^{104}$ Though there may be little to criticize of this pro-active approach, it frustrates judicial discourse in the area as much of the analysis must engage with hypothetical Australian cases ${ }^{105}$ or be grounded upon

97 White-Smith Music Publishing Co v Apollo Co 209 US 1 (1908).

98 Note that in Galaxy Electronics Pty Ltd v Sega Enterprises Ltd (1997) 145 ALR 21 Wilcox J discusses 'Moonlight Sonata' as being read within the bounds of the statute so as not to come to an illogical conclusion that might result in every piano playing Moonlight Sonata being classed as a 'sound recording'.

99 B Johnston, 'Rethinking copyrights treatment of new technology: strategic obsolescence as a catalyst for interest group compromise’ (2009) 64 NYU Ann Surv Am L 165, 170.

100 Ibid 171.

101 See the need for analysis of American jurisprudence in J Ginsberg, 'Separating Sony sheep from Grokster (and Kazaa) goats: Reckoning future business plans of copyright-dependent technology entrepreneurs' (2008) 19 AIPJ 10, 12.

102 Sony Corp of America v Universal City Studios Inc 464 US 417 (1984).

103 Recording Industry Association of America v Diamond Multimedia System Inc 180 F3d 1072 (9th Circuit 1999).

104 Note that the most profound examples being the Copyright Amendment (Digital Agenda) Act 2000 (Cth) and the US Free Trade Agreement Implementation Act 2005 (Cth).

105 In Galaxy Electronics Pty Ltd v Sega Enterprises Ltd (1997) 145 ALR 21 Wilcox J is forced to

Public Space: The Journal of Law and Social Justice (2010) Vol 5, Art 6, pp 1-24. 
American cases. ${ }^{106}$

With the development of broadband technologies Australia has been forced to engage many of the issues before its western counterpart (especially in P2P software distribution cases $^{107}$ and ISP secondary liability for P2P infringement cases). ${ }^{108}$ However, when Australia was confronted with one of the earliest instances of software piracy it found itself unable to rely on the developments from its western brethren - and was forced in Computer Edge v Apple to offer its own analysis of whether computer programs constituted a 'literary work'. ${ }^{109}$ In many other common law nations the decisions involving computer programs were seen in the context of the copyright developments in the revised Berne Convention. ${ }^{110}$ This was not the case in Australia.

Early judicial discussion was limited almost exclusively to the idea that 'a literary work is intended to afford either information and instruction, or pleasure, in the form of literary enjoyment'. ${ }^{111}$ The trial judge in Computer Edge held that there was no way in which one could logically read the definition of literary work so as to include a computer program. This was despite decisions at the same time in Britain ${ }^{112}$, Canada $^{113}$, South Africa ${ }^{114}$ and the United States ${ }^{115}$ that had found otherwise. In the Federal Court of Appeal there was a reversal. The Court held that the source and object programs were literary works within the meaning of s 32 of the Act. ${ }^{116}$ The Court recognised the limits of the definition and artificially constructed the Act to read that object code was an adaptation of the source code (which even the trial judge had reluctantly held to be a literary work). ${ }^{117}$ It was far from textbook media neutrality, but the Court used media neutral construction of the 'adaptation' provision in order to accommodate the object code of the computer program.

After the Appeal decision the legislature stepped in and confirmed that computer programs were literary works in the Copyright Amendment (Computer Programs) Act 1984. ${ }^{118}$ However, the subsequent Appeal to the High Court was heard in the context of the Act prior to the Amendment.

In a scathing review of the Federal Court of Appeal, Brennan $J$ held that an object program was 'neither a literary work nor any other kind of work and was therefore not

engage the hypothetical 'Moonlight Sonata' problem.

106 In Kabushiki Kaisha Sony Computer Entertainment v Stevens [2003] FCAFC 157 the Full Federal Court relied on video game piracy as it had been engaged by American Courts.

107 Universal Music Australia Pty Ltd v Sharman License Holdings Ltd (2005) 65 IPR 289.

108 Roadshow Films v iiNet (2010) 263 ALR 215.

109 Re Apple Computer Inc v Computer Edge Pty Ltd [1984] 53 ALR 225.

110 Note the Berne Convention for the Protection of Literary and Artistic Works was amended on 28

September 1979 to accommodate computer programs as literary works.

111 Hollinrake v Truswell [1894] 3 Ch 420 at 441.

112 Sega Enterprises Ltd v Richards [1983] FSR 73.

113 IMB Corporation v Ordinateurs Spirales Inc (1984) 80 CPR (2d) 187.

114 Northern Micro Computers v Rosenstein [1982] FSR 124.

115 Apple Computer Inc v Franklin Computer Corporation (1983) 714 F 2d 1240.

116 Re Apple Computer Inc v Computer Edge Pty Ltd [1984] 53 ALR 225 at 226.

117 Ibid 241.

118 Copyright Amendment (Computer Programs) Act 1984 (Cth).

Public Space: The Journal of Law and Social Justice (2010) Vol 5, Art 6, pp 1-24. 
a "work that is an adaptation" of the source program'. ${ }^{119}$ Further, Deane J firmly held that there was no method of reading 'an object program [as] a reproduction or adaptation'. ${ }^{120}$ The majority agreed, Gibbs CJ even finding that 'in the case of a literary work, the expression must be in print or writing'. ${ }^{121}$ Given the similarity to Boosey Gibbs CJ noted that he 'regretted that the respondents have no remedy in copyright against the appellants who pirated their programs'. ${ }^{122}$ The Chief Justice even went on to admit that:

Although it would no doubt be right to give the Copyright Act a liberal interpretation, it would not be justifiable to depart altogether from its language and principles in an attempt to protect the products of scientific and technological developments which were not contemplated, or only incompletely understood, when the statute was enacted. ${ }^{123}$

In effect he had followed the law to what seemed like an illogical conclusion (allowing piracy to go unpunished). Even with his judicial activist hat on Gibbs CJ could not bring himself to leap beyond the common connotation of the word 'literary'. He concluded that 'important questions of policy arise when it becomes necessary to consider whether copyright protection should be extended to such a thing... and the Courts can act only within the existing statutory framework'. ${ }^{124}$ The decision of the Chief Justice indicated that where the judiciary saw no scope to read words in their most liberal, media neutral sense, then it was a matter to be left to the legislature.

The dissent from Mason and Wilson JJ in Computer Edge supported the finding of the Appeals Court. They reiterated that programs may be 'entitled to protection as adaptations of the original literary works'. ${ }^{125}$ They relied upon the media neutral analysis undertaken by the House of Lords in Anderson v Lieber Code Co. The English Court there had held that a telegraphic code where the words themselves were meaningless could still constitute a literary work. ${ }^{126}$

Despite (and perhaps because of) this apparent disregard for the broad principle of media neutrality the decision has come under scrutiny from the High Court recently. In Ten $v$ Nine the majority rejected an 'artificially narrow construction of the phrase "a television broadcast" in s 87 of the Act. ${ }^{127}$ In Stevens $v$ Sony ${ }^{128}$ the majority affirmed the use of a "principle of media neutrality" that was identified in the United States in Sony Corp of America ${ }^{129}$ and further identified the usefulness of the "staple article of commerce doctrine'. ${ }^{130}$ Stevens is perhaps the only Australian decision to

119 Computer Edge Pty Ltd v Apple Computer Inc (1986) 65 ALR 33 at 50 (Brennan J).

120 Ibid 59 (Deane J).

121 Ibid 35 (Gibbs CJ).

122 Ibid 38 (Gibbs CJ).

123 Ibid 40 (Gibbs CJ).

124 Ibid 42 (Gibbs CJ).

125 Ibid 49 (Wilson J, Mason J agreed).

126 DP Anderson \& Co Ltd v Lieber Code Co [1917] 2 KB 469.

127 Network Ten Pty Ltd v TCN Channel Nine Pty Ltd (2004) 205 ALR 1 at 19.

128 Stevens v Kabushiki Kaisha Sony Computer Entertainment (2005) 221 ALR 448 at 499.

129 Sony Corporation of America v Universal City Studios Inc 464 U.S. 417 (1984).

130 Note that the Staple Article of Commerce doctrine was a concept that the American Court in Sony

Public Space: The Journal of Law and Social Justice (2010) Vol 5, Art 6, pp 1-24. 
articulate the fully balanced notion of the principle of media neutrality, in that a decision grounded in media neutrality is one which is:

strongly protective of new technology [and] foreshadows the dramatic evolution of a product's market. It respects the limitations facing judges where matters of complex and novel technology are concerned [and] avoids the introduction of a "chill of technological development" in the name of responding to copyright infringement. ${ }^{131}$

This was further enunciated in iiNet where the majority concluded that 'the Court's preference in the circumstances is to take a broad approach'. ${ }^{132}$

The Court in Computer Edge, in opting to limit media neutral interpretation of the literary work provision, made one of the most profound decisions in the spectrum of media neutrality. Despite the addition of computer programs into the ambit of the Copyright Act in 1984 and a short amendment in 1986 rewording the fair dealing provisions $^{133}$ there was very little change until the Digital Agenda Amendment in 2000. We saw previously that the Act in 1997 was able to safely accommodate video games as films and we further identified that this was because there was a balance between limited media neutral front-end and limited media neutral back end (fair dealing and other exceptions). This produced a result that largely balanced the interests of copyright stakeholders. If the Act as assessed by the Court in Computer Edge was so similar to that assessed in Sega why are the results so different? Why does the Act accommodate one technological evolution, but not another?

\section{The solution applied to past technologies}

It appears that where balance exists between the front and back-end provisions, whether they are media neutral or not, there will exist a relatively balanced procedure for accounting for the interests of the three major stakeholders in copyright. I suggest that where the front and back end provisions are limited in media neutral language and definition then the legislature will need to step in from time to time in order to include technologies where a development is without any analogy.

It is here that our reflection on past technology offers three potential solutions to new technologies.

(1) Media specific front and back end provisions that will need to be amended by the legislature with each subsequent technological development (Piano Rolls).

(2) Limited media neutral front and back end provisions that will need to be amended by the legislature from time to time when technology makes significant leaps (computer programs, video games).

Corp borrowed from the law of patents. The doctrine declares that a technology that is capable of significant legal use cannot be deemed to be illegal merely because it can be used for purposes that may infringe copyright. This has been a concept touched upon by recent Australian cases.

131 Stevens v Kabushiki Kaisha Sony Computer Entertainment (2005) 221 ALR 448 at 499.

132 Roadshow Films v iiNet (2010) 263 ALR 215 at 279.

133 Copyright Amendment Act 1986 (Cth).

Public Space: The Journal of Law and Social Justice (2010) Vol 5, Art 6, pp 1-24. 
(3) Unlimited media neutral front and back end provisions that very rarely need to be amended by the legislature and the scope of which is determined almost exclusively by the judiciary.

Given that the current copyright landscape offers an imbalance that fails to fall into any of these three categories the next issue is how significant the need for change is.

\section{How will the courts deal with emerging technologies?}

In order to properly understand the challenges facing modern copyright we need to assess burgeoning technological developments and their use of content, not merely those challenges engaged in more than twenty years ago when the computer industry first exploded onto the market. Further, because media neutrality itself holds no bias towards particular technologies then an analysis of future technologies should also hold no bias. This means that we should focus on understanding the different types of technologies rather than the technologies themselves. New technologies can thus be divided into three distinct categories: those which present new subject matter, those which offer new media of fixation, and those which provide new means of exploitation. These categories are not closed and there is significant cross-over between some categories.

What follows is a discussion of how and why the previous solutions employed may fail to properly alleviate the imbalance caused by the current Act in the face of emerging technologies.

\section{New Subject Matter}

Broadband Internet has led to the development of user-centric content ('UCC', being websites which aggregate news from various sources as occurs with Google News) ${ }^{134}$ and user-generated content ('UGC', whether it be on Facebook, YouTube or more recently Twitter). These developments pose significant challenges to broad, media neutral interpretation of copyright legislation.

The Courts may find that in some instances much of the material posted to usergenerated portals is capable of protection as a literary work because there may be 'sufficient effort of a literary nature'. ${ }^{135}$ In other cases, and in light of Telstra, ${ }^{136}$ the Court may find that content aggregated on news websites does not qualify for protection as a compilation and perhaps breaches the copyright of the original author of an article. This means that aggregate news websites may be violating the rights of the original publishers of news articles by generating their list entirely from precreated content. ${ }^{137}$ This is far from a novel hypothetical. In the United States publishers have pressured the Federal Trade Commission to rule that republishing excerpts from articles in this way contravenes copyright ${ }^{138}$ and a number of major

134 Other sites include Bing! News and Yahoo News.

135 IceTV Pty Ltd v Nine Network Australia Pty Ltd [2009] 254 ALR 386 at 411.

136 Telstra Corp Ltd $v$ Phone Directories Company Pty Ltd [2010] FCA 44.

137 N Anderson, 'Is permission needed to retweet hot news?' Ars Technica. $\left(6^{\text {th }}\right.$ April 2010) (Available at: http://arstechnica.com/tech-policy/news/2010/04/is-permission-needed-to-retween-hot-news.ars).

138 S Desanti, (Chair) [Transcript] Federal Trade Commission: Policy Planning Workshop (7 March

Public Space: The Journal of Law and Social Justice (2010) Vol 5, Art 6, pp 1-24. 
newspapers are creating user agreements that purport to outlaw the reproduction of news article titles. ${ }^{139}$

A number of Australian bodies have attempted to offer guidance in this area. The Australian Copyright Council firmly argues that UGC is protected by copyright as a 'literary work' unless it is too short. ${ }^{140}$ The University of Queensland actually indicates to students that the provisions were not intended 'to directly cover web 2.0' and that 'the law has been slow to adapt to how people use copyright material' in the digital age. ${ }^{141}$ Further, the Australian Digital Alliance and the Australian Library Information Association have indicated to members of their organisations that content is most likely regulated by End User Licence Agreements which purport to transfer copyright to the company running the technology. ${ }^{142}$ It is evident that even the major bodies involved in copyright on a regular basis have yet to come to a consensus on how UGC is protected.

Looking at the legislation itself, the Copyright Act seeks to promote the 'exploitation of new online technologies ${ }^{143}$ and to 'promote access to copyright material online'. ${ }^{144}$ Whilst the object of the Act is clearly stated, the scope of the provisions that one would consider UGC to be within lack similar clarity.

Literary works have been defined to include maps, charts, and computer programs ${ }^{145}$ and the Court in IceTV asked themselves whether 'slivers of information themselves [could] be classified as original literary works'. ${ }^{146}$ The Court went on to find that 'literary works' require a semblance of 'sufficient skill and labour'. ${ }^{147}$ Whether UGC satisfies these elements is entirely a question of fact. Supposing that the content is protected as a literary work, how do the current fair dealing provisions and numerous exceptions offer the broad use that the nature of the content requires? The fair dealing exceptions relevant may be criticism and review ${ }^{148}$ or the reporting of news. ${ }^{149}$ However, this would mean that when UGC and UCC are reposted without permission on another site (which is common), it would have to be done within the parameters of these fair dealing provisions.

Suppose that a user posts on Twitter an account of their experience during the Haiti earthquake: do they own copyright in the 160 characters typed? What if that is

2010) <Available at: htc-01.media.globix.net/COMP008760MOD1/ftc_web/transcripts/030910_sess1> 139 H Tabuchi, 'Nikkei restricts links to its new website'. The New York Times. ( $8^{\text {th }}$ April 2010) <Available at: http://www.nytimes.com/2010/04/09/technology/09paper.html?ref=business >.

140 Australian Copyright Council, Information Sheet: User-Generated Content and Web 2.0 websites. (March 2009).

141 A Austin, (2009) Blog, Podcast, Vodcast and Wiki: Copyright Guide for Australia. University of Queensland, $\mathrm{p} 7$.

142 M McAllister, 'From illuminated manuscript to iPod: Copyright Problems in the Digital Age'. inCite Vol 26 Issue 12 (December 2007), 3.

143 Copyright Amendment (Digital Agenda) Act 2000 (Cth) s 3(a)(ii).

144 Ibid s 3(a)(iii).

145 Copyright Act 1968 (Cth) s 10.

146 IceTV Pty Ltd v Nine Network Australia (2009) 254 ALR 386 at 387.

147 Ibid.

148 Copyright Act 1968 (Cth) s 40.

149 Ibid s 42.

Public Space: The Journal of Law and Social Justice (2010) Vol 5, Art 6, pp 1-24. 
reposted by hundreds of news outlets? Is this valid use of the fair dealing provision? The following was posted in January 2010 and subsequently reported by dozens of news entities:

Consulted [the FirstAid iPhone app] while trapped under Hotel Montana in Haiti earthquake, to treat excessive bleeding and shock. Helped me stay alive till I was rescued 64 hours later. ${ }^{150}$

It is up for debate whether the post qualifies as a literary work - certainly it is original, but our copyright legislation is not determined by originality - the question is whether it is a "literary work in which copyright subsists" ${ }^{151}$ based on the elements outlined above. If it is, it has certainly been published ${ }^{152}$, but what of the reposting on news websites (or to complicate matters even more, on an aggregate news website)? Is this within the ambit of fair dealing? Given narrow construction it may not be. Even if one were to attempt to utilize the as yet undefined s $200 \mathrm{AB}^{153}$ (the 'social use' provision) the Court would be forced to assess each posting of content on its own facts to determine whether the use of copyright material was 'socially useful' in the circumstances. Unfortunately, although the potential to offer sufficient fair use to UCC in Australia was recognised by the Federal Court of Appeal in IceTV (drawing upon Hill J in Skybase), ${ }^{154}$ the High Court subsequently dismissed the 'fair use' idea that a person 'may rework the work of a plaintiff, capturing the ideas used or facts... in a way that does not infringe' copyright. ${ }^{155}$

Not only does this identify the problem of a narrow back-end, it also illuminates a problem with the medium-centric focus of the front-end provisions of the Act. There is only limited focus on originality as the determinative factor in offering copyright to a user-generated work ${ }^{156}$ - so for all it's media neutral ambitions, the Act is still limited to the term 'literary works'.

The major problem we have identified here is that user-centric content is by its nature used commonly in a way that appears to breach traditional copyright boundaries. Most of the uses (reposting content, aggregating news headlines, user posts on social networking sites) require a wider permitted use of copyright material than the law currently allows. Businesses have stepped in to define limited free use in Terms of Use agreements so that the content posted by users is protected within broad free-use boundaries ${ }^{157}$. However, more recently a number of popular user-centric sites (such as

150 A Moses, 'Haiti Survivor: Saved by first-aid iPhone app'. Sydney Morning Herald. (21 January 2010). It was published as a review on iTunes and later 're-tweeted' on Twitter.

151 Copyright Act 1968 (Cth) s 189.

152 There are no limits placed upon the term 'published' under s 33 (2) of the Copyright Act 1968

153 Note that under s 200AB it is a full defence to infringement if the use can be classed as a 'special case' (defined in the TRIPs Agreement).

154 Skybase Nominees Pty Ltd v Fortuity Pty Ltd (1996) 36 IPR 529 at 532 (Hill J with whom French J agreed).

155 IceTV Pty Ltd v Nine Network Australia (2009) 254 ALR 386 at 390.

156 Note that 'originality' is paramount in the United States, see Galoob Toys Inc v Nintendo of America Inc (1992) 964 F 2d 965 ( $9^{\text {th }}$ Circuit).

157 Note for example the challenging privacy issues raised around Facebook.

Public Space: The Journal of Law and Social Justice (2010) Vol 5, Art 6, pp 1-24. 
Facebook) ${ }^{158}$ have begun to claim copyright in the material posted by users (if only for a limited period of time). Until copyright law steps in to clarify the limits of copyright in UCC the business models will continue to use (and in some instances abuse) the content of its users.

\section{New Media of Fixation}

Looking back upon the history of copyright, the type of problem one would assume to be the simplest to comprehend is when new mediums of fixation are introduced (for example, from vinyl records to tape then to CD and to iPod). However, the problem can become very complicated when looking at the growth of cloud-based digital media. There is no doubt that the general public underestimates just how fast cloudbased computing will grow. Cloud computing is core to the web 2.0 experience. It is a system whereby users can stream content from a central server without necessarily keeping a permanent copy of their files on the hard disk of the computer they use to access the content. ${ }^{159}$ Most web-based email clients are considered to be early representations of cloud computing technologies. Before any analysis begins it is apparent that a technology that does not employ any constant, 'fixed' medium poses a problem for copyright which still relies on notions of 'storage' and 'embodiment'.

An ideal example is the revolutionary platform developed by Valve, a cloud-based video game distribution system known as Steam. ${ }^{160}$ Video games are currently protected under the definition of cinematograph films in the Act. ${ }^{161}$ The games under the Steam system will soon be streamed directly to a users computer or console - so that there will be no physical media (such as a disc or hard drive) on which the game is permanently stored. However, the Act requires that a film be 'embodied in an article or thing, ${ }^{162}$ The whole ('the aggregate of visual images') ${ }^{163}$ of the video game will at no point be embodied on the users console and only the segment relevant to the point-in-time enjoyment of the game is present in the RAM module - and the RAM alone is not capable of constituting the 'reproduction in material form'. ${ }^{164}$ Even if one applies the liberal interpretation of the embodiment principle in s 24 as the Court did in Sega (finding that the provision is designed so as not to be read narrowly) ${ }^{165}$ the requirement of the embodiment of the content on any article or thing cannot be ignored. The game itself exists on a server (often multiple servers) thousands of kilometers away. Suppose that the game exists on a swarm of servers from various locations, constantly alternating with the broadband demands of users. In Sharman the High Court noted that the swarm of servers involved in P2P networks fell outside the

158 See the Statement of Rights and Responsibilities at http://www.facebook.com/terms.php?ref=pf 159 C Foresman, 'Heavenly jukebox: cloud distribution and the future of film'. Ars Technica. (2 April 2010) $<$ Can be found at: arstechnica.com/media/news/2010/04/the-cloud-gives-independent-film-awider-audience-for-less-money-ready-to-edit.ars $>$.

160 A Webster, 'The future of gaming: up the beanstalk and into the cloud'. Ars Technica. (5 April 2010) <Can be found at: arstechnica.com/business/future-of-cloud/2010/04/cloud-gaming.ars > .

161 Copyright Act 1968 (Cth) s 10.

162 Ibid.

163 Ibid.

164 Australian Video Retailers Association v Warner Home Video Pty Ltd (2001) 114 FCR 324 at 341. 165 Galaxy Electronics Pty Ltd v Sega Enterprises Ltd (1997) 145 ALR 21 at 22.

Public Space: The Journal of Law and Social Justice (2010) Vol 5, Art 6, pp 1-24. 
ambit of copyright because there was no embodiment of an entire file on a central server. ${ }^{166}$ If the Courts took a similar approach there would be a challenge to considering a game existing in the 'cloud' as being embodied on an article or thing.

Suppose that this is enough of an embodiment to foster protection for the video game - what of piracy? If the practice of piracy adopts the streaming platform then at no point is there a sufficient 'copy' of the game as defined by the Act to constitute the user making an 'infringing copy' of the cinematograph film. ${ }^{167}$ Perhaps the Court would be willing to read the temporary RAM storage as a copy so that streaming piracy is successfully classed as being covered as an 'infringing copy'. However, if storage in RAM is classified as a copy then this has significant ramifications for digital media and computer programs.

In Australian Video Retailers the majority held that the "ephemeral embodiment of... the visual images...in the random access memory (RAM) of a DVD player or personal computer...does not constitute the act of making a copy'. ${ }^{168}$ Then in Stevens the Court held that RAM storage of the computer program 'did not entail reproduction of it in a material form'. ${ }^{169}$ There has been a pragmatic attempt to limit the scope of copies where the RAM module is concerned. Otherwise it would mean that every time a user listens to a music track on their computer there is a 'copy' played through the RAM module. Under what circumstances would this copy be an 'infringing copy'? In the US, however, RAM copies are classed as reproductions, but have been subject to fair use. ${ }^{170}$

This example highlights that the specific space-shifting and time-shifting exceptions suggested by recent reform commissions ${ }^{171}$ would fast become redundant in a digital world where there is no specific space or time-based origin of a work. Even Screenrights Australia has argued that these exceptions (and specifically the potential breadth of s 110AA) undermine the business models that are driving the uptake of digital technology. ${ }^{172}$ It also offers a modern version of the problem in RIAA $v$ Diamond Multimedia ${ }^{173}$ where the Courts in the United States were asked whether transferring of a music file onto a RIO portable music player constituted fair use which they ultimately held it did. ${ }^{174}$ Had they held otherwise then the iPod and all other digital music technologies would have been extremely limited. The 'space shifting' exception to copyright (which has not been confirmed by the Parliament or

166 Universal Music Australia Pty Ltd v Sharman License Holdings Ltd (2005) 65 IPR 289 at 290.

167 See Copyright Act 1968 (Cth) s 10 for the definition of 'infringing copy'.

168 Australian Video Retailers Assoc'n v Warner Home Video Pty Ltd (2001) 114 FCR 324 at 341.

169 Stevens v Kabushiki Kaisha Sony Computer Entertainment (2005) 221 ALR 448 at 471.

170 BD Johnston, 'Rethinking copyrights treatment of new technology: strategic obsolescence as a catalyst for interest group compromise'. (2009) 64 NYU Ann Surv Am Law 165, 190.

171 See the recent Issues Paper: Copying Photographs and Films in a different format for Private Use - a review of sections 47J and 110AA of the Copyright Act 1968 (January 2008), 11.

172 S Lake, 'Submission: review of sections 47J and 110A of the Copyright Act 1968', Screenrights Australia (29 February 2008).

173 Recording Industry Association of America v Diamond Multimedia Systems Inc. (1999) 180 F 3d 1072 (9th Cir.).

174 Ibid.

Public Space: The Journal of Law and Social Justice (2010) Vol 5, Art 6, pp 1-24. 
judiciary per se) offers a safe harbour for development of all of these types of technology.

The medium-requisite in the definition of terms has thus far led to inconsistent results and makes it difficult to consider how the Courts would classify streaming services. On the one hand, Lindgren and Finkelstein JJ argued in Stevens that the ambiguity in the Act 'sustained the broader approach urged by [Sony Corp of America]'175 - in which case the Court would look to the content and the purpose of the Act rather than the technicalities of s 110 (the cinematograph film provision). The logical conclusion would be protection of the video game stored on the server subject to the fair use of the end-user. However, both the High Court in Stevens ${ }^{176}$ and the Federal Court of Appeal in IceTV $V^{177}$ urged that there is only limited breadth in the Act to read content beyond the technical limitations of the relevant provisions. In this instance the Act is unable to deal with the absence of a 'medium' for the embodiment of a work. Copyright protection is thus medium dependent and there is the potential for the abuse of the front-end if the back-end is not read broadly.

\section{New Means of Exploitation}

If there appears to be a gap between where the legislation currently is and where it should be in order to accommodate new subject matter and new media of fixation, then it pales in comparison to the gulf that exists when trying to accommodate new means of exploitation. In the past new means of exploitation included library access to books ${ }^{178}$ and rentals of films. ${ }^{179}$ In the digital age we have been confronted by new web-based exploitation models for existing content. This has been most profound in blurring the line between commercial and academic uses of student papers where antiplagiarism databases are concerned. The tentpole focus is Turntin.com.

The turnitin.com service is a web-based plagiarism detection service that seeks to 'stop the spread of internet plagiarism'. ${ }^{180}$ A university student may be required to upload their paper to the service in order to have the paper checked for plagiarism against a database of millions of student and academic writings. Once uploaded the student paper often becomes part of the archive. In June of 2007 four American high school students brought an action for infringement of copyright of their research papers against the plagiarism prevention database turnitin.com (AV v iParadigms). ${ }^{181}$ It was alleged that if an academic paper was uploaded to the database by the school and the paper was subsequently archived to be used to assess future submissions, then

175 Kabushiki Kaisha Sony Computer Entertainment v Stevens [2003] FCAFC 157 at 183 (Lindgren J Finkelstein J concurred on this point).

176 Stevens v Kabushiki Kaisha Sony Computer Entertainment (2005) 221 ALR 448 at 450.

177 Nine Network Australia Pty Ltd v IceTV Pty Ltd [2007] FCA 1172 at 1173.

178 M Wyburn, 'Higher education and fair use: A wider copyright defence in the face of the AustraliaUnited States Free Trade Agreement changes'. (2006) 17 AIPJ 181 at 185.

179 Australian Video Retailers Assoc'n v Warner Home Video Pty Ltd (2001) 114 FCR 324.

180 iParadigms LLC's Turnitin. About Us. http://www.turnitin.com/static/company.html

181 AV v iParadigms LLC (2008) USDC (EDV) 07-0293.

Public Space: The Journal of Law and Social Justice (2010) Vol 5, Art 6, pp 1-24. 
it was not a fair use with respect to the Copyright Act 1976 (US). ${ }^{182}$ At first instance ${ }^{183}$ and on appeal ${ }^{184}$ it was held that archive of the papers in this way constituted 'fair use', notwithstanding that turnitin.com was 'selling its services without giving ...any compensation'. ${ }^{185}$

However, if a case were to be brought by university students in Australia then the result could differ significantly. The principle problem for the American Courts was whether archiving of the material constituted fair use. ${ }^{186} \S 107$ of the American legislation classes 'study', 'scholarly use', 'research', 'criticism', and 'review' all under one general fair use defence that is not limited to these terms. Critically, the Australian provision that contains the criteria (section 40) is limited to the dictionary definitions of 'research ${ }^{187}$ and 'study' only. ${ }^{188}$ It is not a general fair use provision as it is in the United States.

Arguably, the conduct involved in the storage of documents to assess plagiarism is merely the 'gathering of information' and as such is not for the purpose of study or research (as was held in Re Attorney-General of British Columbia and Messier). ${ }^{189}$ It would seem that in light of the Federal Court finding in Haines ${ }^{190}$ s 40 does not include teaching purposes (which is the purpose with which the universities and turnitin.com are engaged). The social benefit exception (s 200AB) fails to offer a safe harbour for turnitin.com because the service gains a commercial benefit. ${ }^{191}$

How could a service, which purports to offer a strong social benefit (anti-plagiarism), fail to be within the ambit of Australian copyright legislation? Despite the Court generally preferring 'to take a broad approach to the Act' ${ }^{192}$ there is a failure of the fair dealing provisions to properly balance the media neutral rights offered by the front-end of the Act. Further, is the university involved potentially liable for 'authorising' the infringement? Given the broad definition outlined by the Court in Cooper $v$ Universal ${ }^{193}$ there appears to be potential for university students to take action against the university as well.

18217 USC $\S 107$.

183 Above $n 181$.

184 AV v iParadigms LLC (2009) USCA ( $4^{\text {th }}$ Cir) 08-1424.

185 R Staino, 'Courts: Turnitin doesn't violate students' copyright'. School Library Journal (30 April 2009).

186 The closest Australian equivalent to the fair use exceptions are outlined in the Copyright Act 1968 (Cth) ss 40-42.

187 Re Hoyts Multiplex Cinemas Pty Ltd and City of Gosnells [1997] WAICmr 1 at 26 (Cmr KeighlyGerardy quoting Beaumont $\mathrm{J}$ in De Garis).

188 De Garis v Neville Jeffress Pidler Pty Ltd (1990) 95 ALR 625 at 630 (Beaumont J).

189 (1984) 8 DLR (4 ${ }^{\text {th }}$ Circuit) 306.

190 Haines $v$ CAL (1982) 42 ALR 549.

191 Copyright Act 1968 (Cth) s 200AB.

192 Roadshow Films v iiNet (2010) 263 ALR 215.

193 Cooper v Universal Music Australia (2006) 237 ALR 714 at 123 (Kenny J) held that "the law in Australia attributed a wide meaning to the word "authorise" in this context.

Public Space: The Journal of Law and Social Justice (2010) Vol 5, Art 6, pp 1-24. 
In the above examples we can see how obsolete specific media are becoming and with media specific exceptions the legislature will need to constantly update the legislation to reflect changes in technology, and piracy may forever manage to keep a step ahead of the law.

\section{Problems with New Technologies}

Through these burgeoning technologies we can see a particularly wide gap between what we currently have and what we need to deal with them. Is our Act capable of adopting these technologies? It appears so.

But if the Court is willing to broaden the scope of these rights-giving provisions to encompass these new technologies, do we have the sufficient back-end (rightslimiting) provisions in order to allow various types of uses of UGC and be able to use consolidated news sites and to allow use of commercial databases for academic uses? At the moment, we have a narrow back-end, and it prima facie appears that we may not be able to properly protect 'fair uses' of these technologies. The nature of new technologies questions whether copyright has a place in the digital environment in only a limited way or whether it need exist at all.

\section{Conclusion}

In one sense, and because copyright underpins most of the existing content creation and distribution models, the question is not so much whether copyright should exist at all, but how we should adapt our current copyright infrastructure to better provide for stakeholder balance in the face of emerging technologies.

With an over-specific, complicated and increasingly cumbersome copyright law colliding with the reality of digital technology, the need for simplification and a rational rethinking of how best to maintain the delicate balance is abundantly clear. There is a 'serious question whether the set of constructs that make-up the Copyright Act...is sufficient to deal with the peculiar stresses produced by the application of... anticipated digital technology'. ${ }^{194}$ Further, with the development of user-centric technologies, it seems clear that the ideological and economic parochialism that has dominated legislative reform must give way to a balanced media neutral approach, mindful of streamlining the copyright legislation.

As it is, the Courts have had difficulty broadening the scope of the Copyright Act to cover new technologies - the inconsistent results being the quintessential example of the confusion the Courts have found when confronted by the imbalance between broad, media neutral front-end provisions and narrow media-specific back-end provisions. Even where the Courts have recognised copyright law as coming to illogical and inconsistent conclusions, they have held that policy-centric decisions 'must be left to others in the executive government and the Parliament itself' ${ }^{195}$ The Parliament is reluctant to engage in policy-making vis-à-vis copyright itself,

194 Halpern, n 1, 310.

195 Stevens v Kabushiki Kaisha Sony Computer Entertainment (2005) 221 ALR 448 at 492 (Kirby J).

Public Space: The Journal of Law and Social Justice (2010) Vol 5, Art 6, pp 1-24. 
preferring to leave it to the judiciary to interpret the imbalanced legislation. ${ }^{196}$ This appears to be a never-ending spiral of lawmakers off-loading responsibility.

Although copyright is itself a product of technology, that should not take away from the fact that it operates as the platform to facilitate balanced exploitation of the creative possibilities of new technologies. Copyright law has forever required the existence of fixed mediums and technologies in which to empower rights - it has needed technology - but if the law fails to adapt to the changing digital climate and alleviate the stakeholder imbalance between front and back-end rights, it may just find that technology doesn't need it anymore. 